Pease, P. (1956). J. gen. Microbiol. 14, 672-675

\title{
The Gonidial Stages in Spirillum spp. and Vibrio spp.
}

\author{
BY PHYLLIS PEASE \\ Department of Bacteriology, University of Birmingham
}

SUMMARY: In twelve strains, comprising three species of saprophytic Spirillum and two of Vibrio, a life cycle was observed in which small gonidia, resembling very tiny bacteria, sometimes motile by means of polar flagella, were formed within enlarged mother-cells. After a period of reproduction in this phase, the gonidia became progressively enlarged to reconstitute the original form. In one species of Spirillum, the cycle was induced by the addition of penicillin to the medium, and in this and certain other respects was reminiscent of the L-cycle.

Reports of gonidial reproduction in bacteria have frequently been made. These fall into three categories : the L-cycle, which has frequently been described but is still not well understood; cycles in which ultramicroscopic units take part, for example in Mycobacterium tuberculosis, and which are even less well understood; and thirdly, the gonidial cycle in which the reproductive units appear to resemble very small bacteria, frequently motile by means of polar flagella, and are formed within mother-cells. Examples of the last class, which is the subject of study, may be found in the literature from quite an early date. However, only recently have convincingly illustrated accounts been available, especially of spirochaetes (Hampp, Scott \& Wyckoff, 1948; DeLamater, Haanes, Wiggall \& Pillsbury, 1951) and of the aerobic nitrogen-fixing bacteria, Rhizobium spp. (Bisset \& Hale, 1951) and Azotobacter spp. (Bisset \& Hale, 1953). Although the taxonomic borderline between spirilla and spirochaetes is not well-defined, it appears that a properly documented account of gonidial reproduction in the large saprophytic spiral bacteria, and in the shorter forms, usually described as vibrios, is not so far available, and it is the purpose of this paper to present such evidence, as well as to examine certain aspects of this phenomenon in which it resembles, or alternatively is distinct from, the L-cycle.

\section{METHODS}

Twelve strains of bacteria of spiral morphology were isolated by adding approximately $0 \cdot 2 \%(\mathrm{w} / \mathrm{v})$ of 'Difco' peptone to $25 \mathrm{ml}$. pond-water in a Petri dish. This was left at room temperature $\left(c .25^{\circ}\right)$ for $48 \mathrm{hr}$. and the surface layer removed by pipette, transferred to a sterile atomizer and sprayed over plates of the sodium acetate medium described by Pringsheim \& Robinow (1947). Colonies recognizable under the plate microscope as consisting of spirilla were picked off and subcultured on the same medium. In the case of Spirillum volutans strains, which failed to grow on this medium, cultures were obtained by inoculating tubes of an infusion of wheat-grains and soil which had been steamed on three successive days (Pijper, 1949). 
Impression preparations were made according to the method of Klieneberger-Nobel (1949). For electron microscopy cultures were grown on collodion membranes over the same medium (Hillier, Knaysi \& Baker, 1948). These were examined at periods varying from $3 \mathrm{hr}$. to 5 days of incubation at $25^{\circ}$.

Preparations were shadowed with $\mathbf{4 0} \%$ palladium/gold and were examined under a Metropolitan-Vickers electron microscope EM3, at $75 \mathrm{kV}$ intensity.

\section{RESULTS}

According to the diagnoses of Giesberger (1936), Myers (1940) and Bergey's Manual (1948) the bacteria isolated were classified as Spirillum serpens (4 strains), $S$. undula (6 strains), $S$. volutans (2 strains). In addition, an undiagnosed strain of Vibrio, isolated from pond-water, was examined. All these showed the gonidial life cycle. In addition, several strains of spiral bacteria were isolated having the characters of Spirillum, Vibrio and Caulobacter spp., in which this type of life cycle was not observed.

Spirillum undula. The entire cycle was usually complete in about 5 days. The normal form of the spirillum was approximately $1 \mu$. in diameter and from 20 or $30 \mu$. to as much as $100 \mu$. in length. Most frequently the organisms had $2 \frac{1}{2}$ to 3 complete coils, and possessed 20-30 flagellar fibrils at each pole (Pl. 1, figs. 1,4$)$. The beginning of the gonidial cycle was marked by the appearance of swellings, from one to three, but seldom more in number, along the length of the spirillum. From their first appearance, these swellings were seen to contain numerous small granules (Pl. 1, figs. 2-5). The swellings and the granules which they contained increased in size at the apparent expense of the spirillum (Pl. 1, figs. 4, 5), until the latter had almost disappeared. The swellings first appeared after $48 \mathrm{hr}$. of incubation, and the initial process was complete usually at the conclusion of a further $24 \mathrm{hr}$. Thereafter, the granules became freed from the mother-cells, in the form of tiny, slightly curved bacteria, actively motile by means of polar flagella (Pl. 2, fig. 6). These gonidia appeared to reproduce by fission. They also grew considerably in size, and by the end of 2-3 days were restored to the original condition of the parent organism. The entire cycle was concluded in a single culture. Of considerable interest was the clear demonstration of blepharoplasts in the gonidia.

Spirillum volutans. This species, considerably larger in size then the preceding one, developed in exactly the same manner, as far as could be determined.

Spirillum serpens. Cultures of this species, which morphologically resembled $S$. undula, grew for periods up to 5 weeks without producing gonidial forms. But it was found that these could be induced at any stage by the addition of 200 units penicillin/ml. to the culture medium (cf. production of L-forms under the influence of penicillin; Pierce, 1942; Klieneberger-Nobel, 1949; Dienes \& Weinberger, 1951)). This process occurred very rapidly, and all stages were visible in a single culture within a few hours of the addition of penicillin. But the cysts did not germinate unless subcultured upon fresh medium 
containing penicillin, when the granules increased further in size and appeared as small cocco-bacillary elements, devoid of flagella. These developed as tiny colonies reminiscent of the G-form colonies described by Hadley (1931) (Pl. 2, figs. 7, 8). On subculture upon medium without penicillin these developed into normal spirilla. When, in the process of this cycle, subculture was made at any stage upon medium which did not contain penicillin, the normal forms immediately outgrew the gonidia, so that further development of the latter was obscured (Pl. 2, fig. 9).

In addition, strains of Spirillum serpens produced organelles resembling motile gonidia by an alternative method. A small bud became detached, apparently by constriction, from the tip of the vegetative spirillum, retaining all the flagella appertaining to that pole; and this small, but highly motile cell proceeded independently (Pl. 3, figs. 10-12). The subsequent fate of these units was not determined.

Vibrio sp. A series of isolates from water taken from a small pond in the vicinity of the laboratory proved to be a small unidentifiable vibrio, about $0.5 \mu$. in diameter (Pl. 4, fig. 13). This organism underwent a type of life cycle similar to that of Spirillum serpens, but initially did so spontaneously. On repeated subculture, however, it was found that the phenomenon appeared only on the addition of 1000 units penicillin $/ \mathrm{ml}$. to the medium. The cycle is illustrated in Pl. 4, figs 13-15.

Vibrio metchnikovii. For comparison with the last-mentioned species, a strain of this pathogenic vibrio was obtained from the National Collection of Type Cultures. In contrast, to the preceding Vibrio sp., V. metchnikovii produced motile gonidia with one or two flagella, very strongly resembling those of Rhizobium (Pl. 4, fig. 16).

\section{DISCUSSION}

The gonidial cycle, both in the large saprophytic spirilla, and in species of Vibrio, appears in two similar but distinct forms. One of these is in all respects the same as the production of 'swarmers' in the nitrogen-fixing bacteria (Bisset \& Hale, 1951, 1953). The reproductive elements are complete tiny bacteria with polar flagella, which reproduce as such but gradually grow into typical parent forms. In other species, however, the gonidia were not motile, and appeared most readily under the influence of penicillin. They manifested themselves as tiny colonies, and had therefore a certain amount in common both with the more perfect types of gonidia and with the so-called G-and L-forms. This condition may reasonably be considered to be in some respects degenerate, and it is of considerable interest that one species, Spirillum serpens, which had thus apparently lost the power of producing motile gonidia by this method, had evolved the system of budding-off motile elements from the tip of the vegetative spirillum. The existence of these tiny reproductive forms in the spiral bacteria serves to explain the phenomenon, well known to those who have worked with them, of sudden, mysterious fluctuations in the populations of these bacteria, both in nature and in artificial culture. It also provides evidence of similarity between the large spirilla and the spirochaetes, where such cycles have been long known. 
Journal of General Microbiology, Vol. 14, No. 3
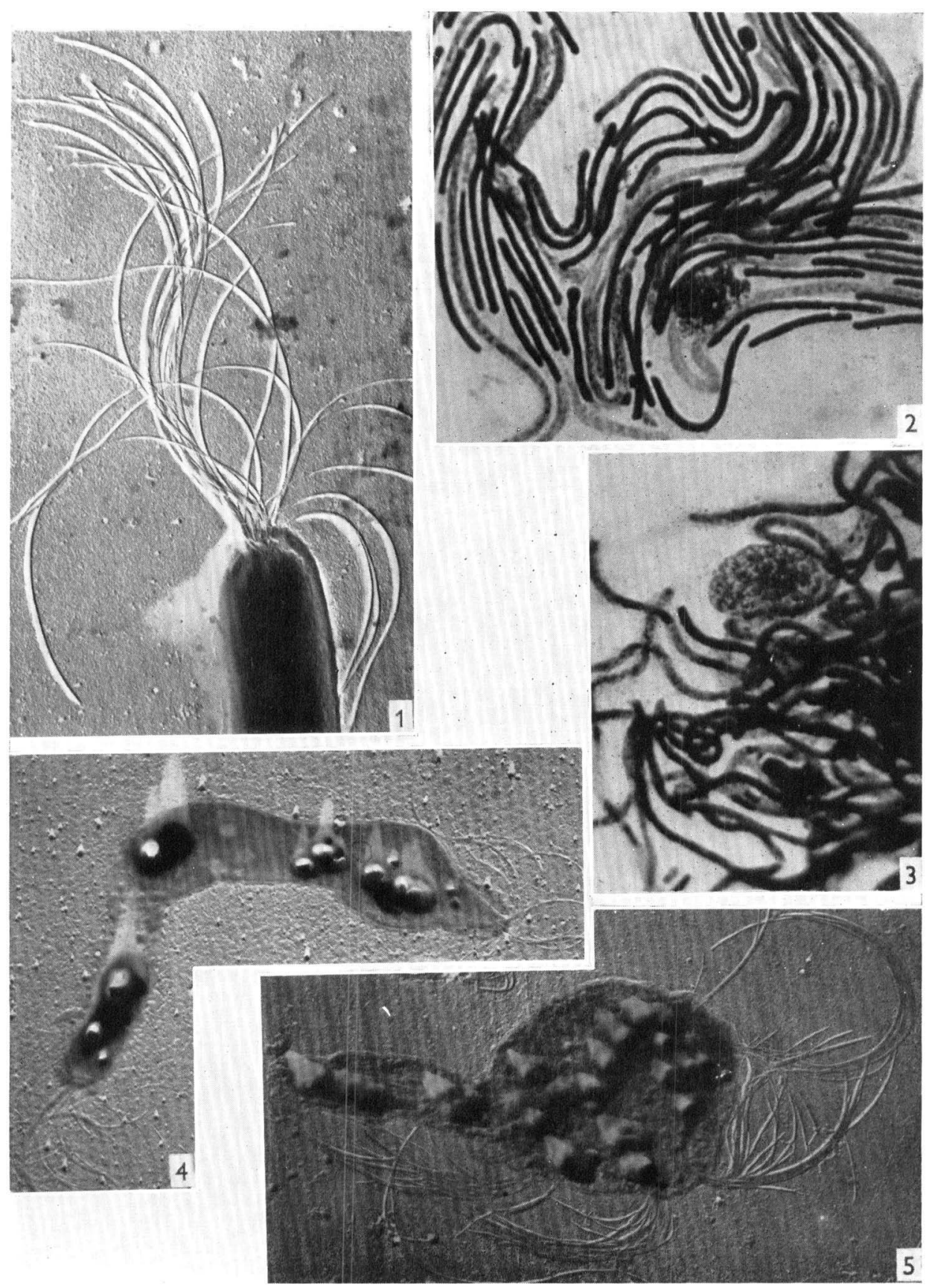

P. Pease-Gonidial stages in Bacteria. Plate 1

(Facing p.674) 
Journal of General Microbiology, Vol. 14, No. 3
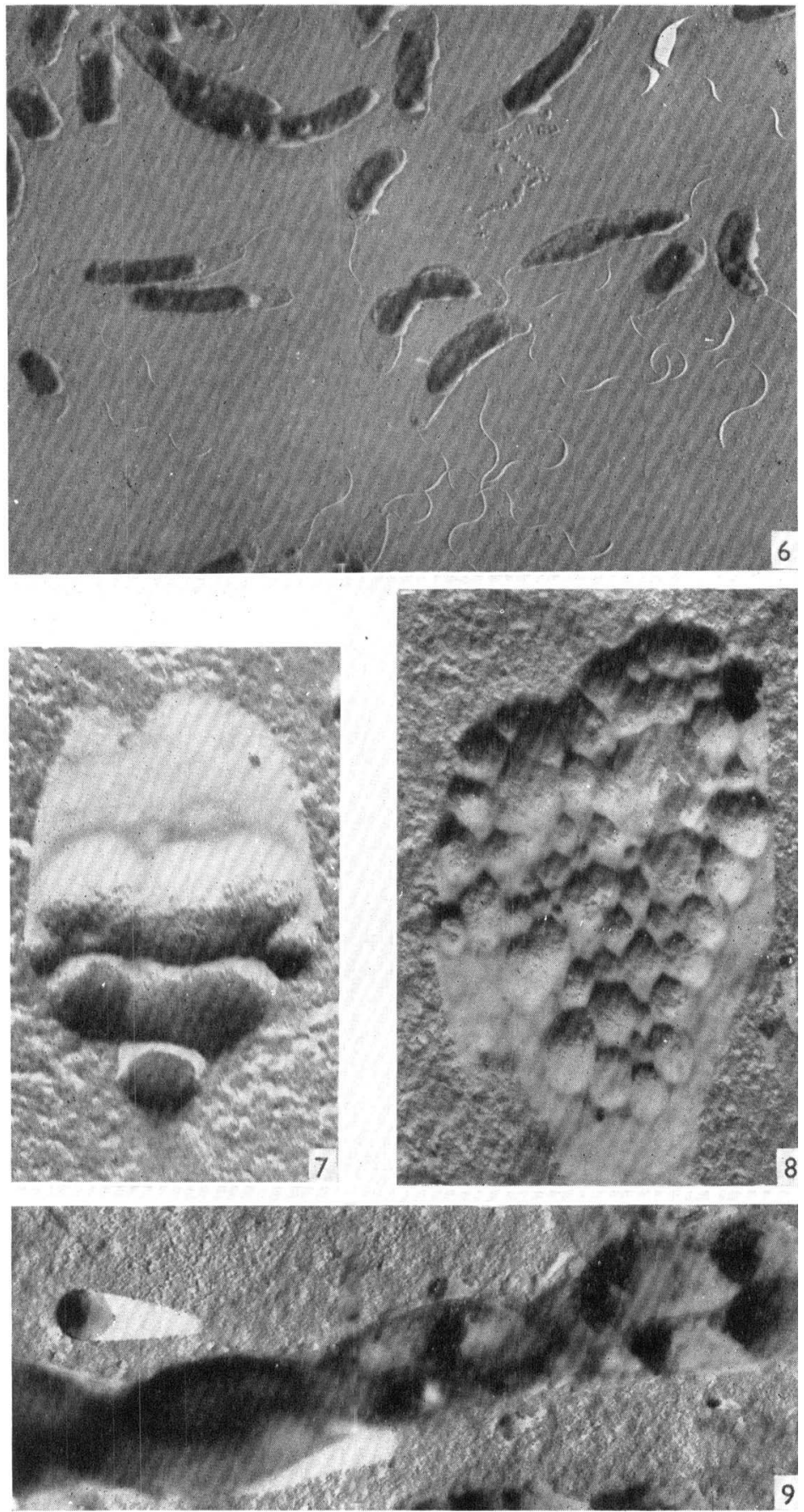

P. Pease-Gonidial stages in bacteria. Plate 2 
Journal of General Microbiology, Vol. 14, No. 3
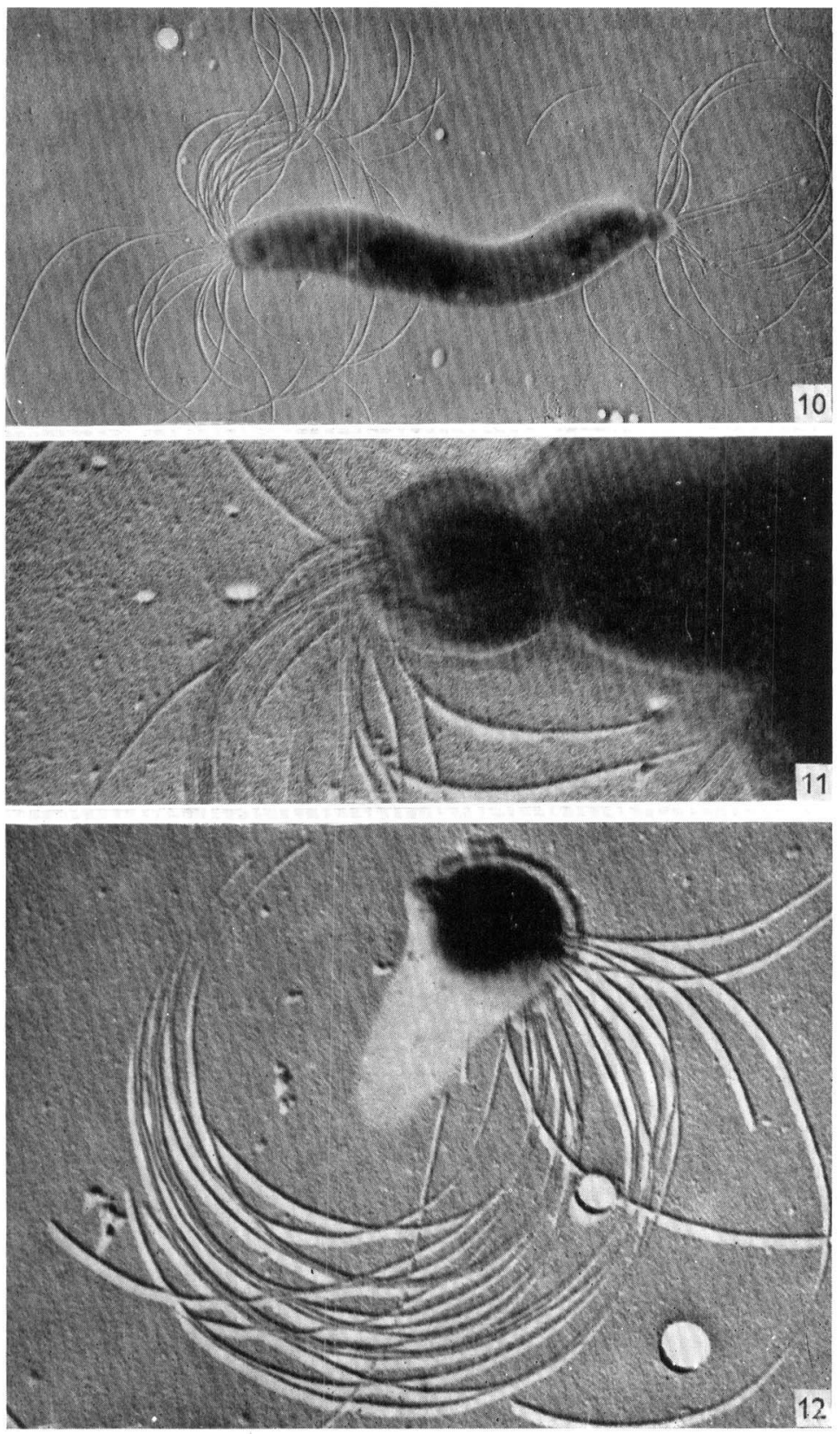

P. Pease-Gonidlal stages in bacteria. Plate 3 
Journal of General Microbiology, Vol. 14, No. 3

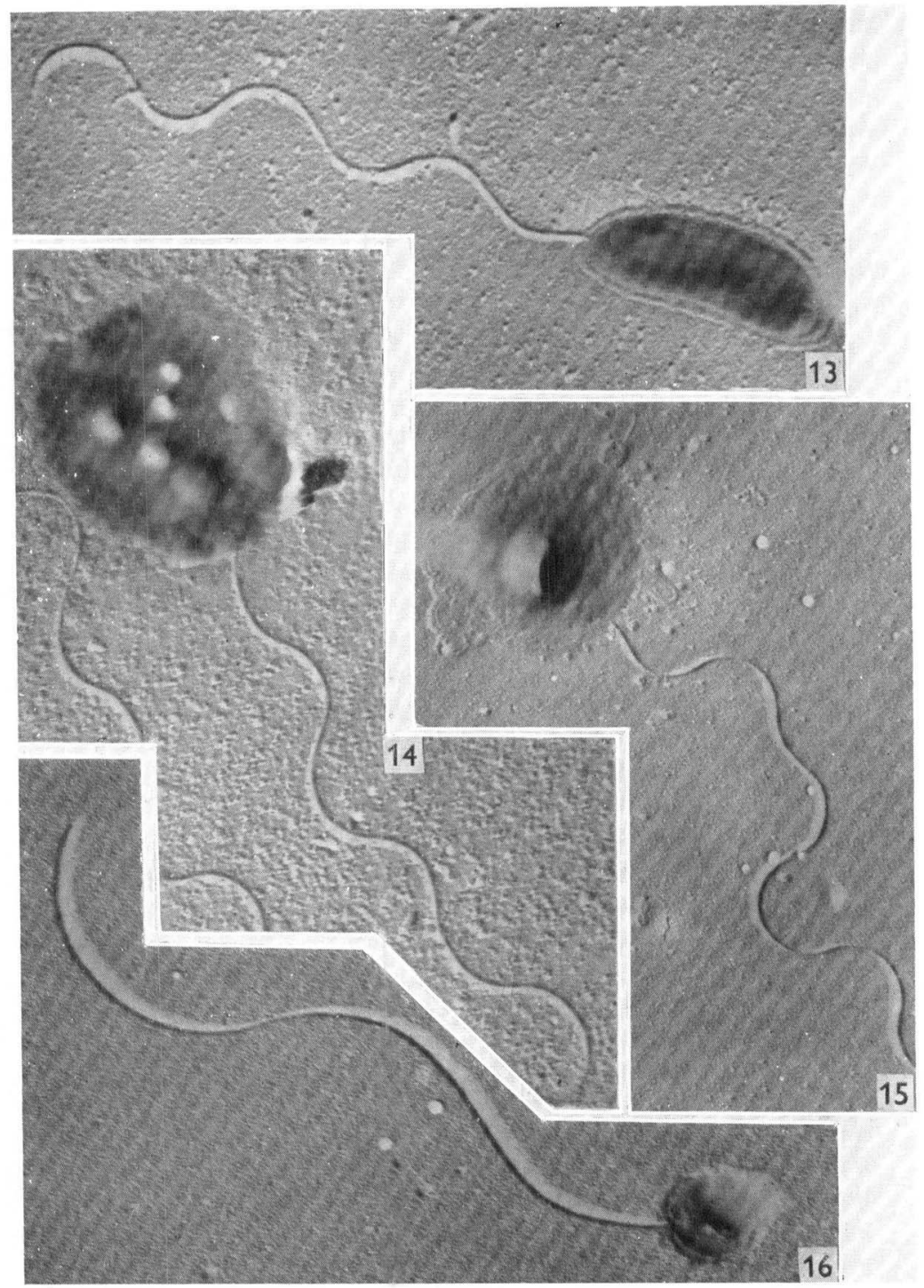

P. Peasl-Gunidial stagles in bactemia. Plate 4 


\section{REFERENCES}

Bergey's Manual of Determinative Bacteriology (1948). 6th ed. Edited by BrEed, R. S., Murray E. G. D. \& Hitchens, A. P. London: Baillière, Tindall and Cox.

Bisset, K. A. \& HALE, C. M. F. (1951). The production of swarmers in Rhizobium spp. J. gen. Microbiol. 5, 592.

Bisset, K. A. \& Hale, C. M. F. (1953). The cytology and life-cycle of Azotobacter chroococcum. J. gen. Microbiol. 8, 442.

Delamater, E. D., Hanes, M., Wiggall, R. H. \& Pillsbury, D. M. (1951). Studies on the life cycle of spirochaetes. VIII. Summary and comparison of observations on various organisms. J. invest. Derm. 16, 231.

Dienes, L. \& Weinrerger, H. J. (1951). The L-forms of bacteria. Bact. Rev. 15, 245.

Gresberger, G. (1936). Beiträge zur Kenntnis der Gattung Spirillum Ehbg. Inaug. Diss., Utrecht. Delft: W. D. Meinema.

HAdLEy, P. (1931). The filtrable forms of bacteria. I. A filtrable stage in the lifehistory of the Shiga dysentery bacillus. J. infect. Dis. 48, 1.

Намpp, E. G., Sсотт, D. B. \& WyскоғF, R. W. G. (1948). Morphologic characteristics of certain cultured strains of oral spirochaetes and Treponema pallidum as revealed by the electron microscope. J. Bact. 56, 755.

Hillier, J., Knaysi, G. \& Baker, R. F. (1948). New preparation techniques for the electron microscopy of bacteria. J. Bact. 56, 569 .

Klieneberger-Nobel, E. (1949). Origin, development and significance of L-forms in bacterial cultures. J. gen. Microbiol. 3, 434.

Myers, J. (1940). Studies on the spirilleae: methods of isolation and identification. J. Bact. 40, 705.

Pierce, C. H. (1942). Streptobacillus moniliformis. Its associated L form, and other pleuropneumonia-like organisms. J. Bact. 43, 780. (Abstr.)

PrJper, A. (1949). The flagella of Spirillum volutans. J. Bact. 51, 111.

Pringsheim, E. G. \& Robinow, C. F. (1947). Observations on two very large bacteria, Caryophanon latum and Lineola longa. J. gen. Microbiol. 1, 267.

\section{EXPLANA'TION OF PLATES}

Plate 1

Fig. 1. Spirillum undula. Flagellar fibrils arising from the pole of the organism. Electron micrograph, $\times 10,000$.

Figs. 2, 3. S. undula. Granular structures within a colony. Impression preparations, $\times 1000$.

Fig. 4. S. undula. Granules within an organism. Electron micrograph, $\times 6000$.

Fig. 5. S. undula. Cyst containing granules. The remains of the organism can be seen still attached. Electron micrograph, $\times 6000$.

\section{Plate 2}

Fig. 6. Spirillum undula. Gonidia with single flagella attached to blepharoplasts. Electron micrograph, $\times 3000$.

Figs. 7, 8. S. serpens. Colonies of cocco-bacillary elements. Electron micrographs, $\times 20,000$ and 10,000 .

Fig. 9. S. serpens. Reversion of elements to spiral form. Electron micrograph, $\times 12,000$.

\section{Plate 3}

Figs. 10, 11. Spirillum serpens. Formation of a bud at the tip of an organism. Electron micrographs, $\times 6000$ and 28,000 .

Fig. 12. S. serpens. A free bud. Electron micrograph, $\times 20,000$.

Plate 4

Fig. 13. Saprophytic Vibrio sp. with one polar flagellum. Electron micrograph, $\times 15,000$.

Figs. 14, 15. Saprophytic Vibrio sp. containing granules. Electron micrographs, $\times 20,000$ and $\times 15,000$.

Fig. 16. Vibrio metchnikovii. Motile gonidium. Electron micrograph, $\times 25,000$.

(Received 12 December 1955) 